\title{
LIFETIME WARRANTY DALAM JUAL BELI DITINJAU DARI PERSPEKTIF HUKUM EKONOMI SYARI'AH
}

\author{
Oleh: Elfa Murdiana, M.Hum dan Aprina Chintya, SH.
}

\begin{abstract}
Abstrak
Lifetime warranty adalah salah satu keunggulan tersendiri bagi suatu produk. Hal ini dikarenakan konsumen dapat menukar produk Lifetime warranty dengan yang baru apabila produk tersebut mengalami kerusakan. Ini memberikan keyakinan kepada konsumen bahwa produk yang ditawarkan benar-benar produk yang berkualitas baik dan memberikan kepuasan terhadap konsumen atas produk yang diberikan. Penelitian ini bertujuan untuk memaparkan lifetime warranty ditinjau dari perspektif hukum ekonomi syari'ah. Berdasarkan hasil analisis yang telah dilakukan bahwa lifetime warranty memiliki relevansi dengan khiyar aib. Ini bisa dilihat dari prinsip-prinsip yang ada dalam lifetime warranty yang sama dengan yang ada dalam khiyar aib. Prinsip-prinsip ini diantaranya adalah prinsip ar-Rhidha, persaingan sehat, kejujuran, keterbukaan dan keadilan. Semua prinsip tersebut juga sesuai dan tidak ada yang bertentangan dengan prinsip-prinsip khiyar aib yang ada dalam hukum ekonomi syari'ah.
\end{abstract}

Kata kunci : Produk, Khiyar Aib, Prinsip, Life Time Warratny

\begin{abstract}
Lifetime warranty is one of its own advantages for a product. This is because consumers can trade Lifetime warranty products with new ones if the product is damaged. This gives consumers confidence that the products offered are truly good quality products and provide satisfaction to the consumers for the products provided. This study aims to describe the lifetime warranty from the perspective of sharia economic law. Based on the analysis that has been done that lifetime warranty has relevance to khiyar disgrace. This can be seen from the principles that exist in the same lifetime warranty that exist in khiyar disgrace. These principles include the principles of ar-Rhidha, fair competition, honesty, openness and justice. All these principles are also appropriate and nothing contradicts the khiyar disgrace principles that exist in Shariah economic law.
\end{abstract}

Keyword : Product, Khiyar Aib, Principle, Lime Time Warranty

\section{A. Pendahuluan}

Persaingan usaha yang semakin ketat di era yang serba modern ini, membuat pengusaha harus menciptakan layanan yang lebih inovatif. Hal ini bertujuan untuk meningkatkan penjualan produknya. Salah satu upaya yang dilakukan produsen adalah dengan memberikan layanan garansi. 
Menurut Arie Siswanto, dalam dunia usaha selalu ada yang dinamakan persaingan bisnis (businesss competition), yang secara sederhana biasa didefenisikan sebagai persaingan antara penjual didalam 'merebut' pembeli atau pangsa pasar. Garansi ini sangat berharga sebab dengan adanya garansi, selain menjamin kualitas produk tersebut juga mepengaruhi harga jual dan minat pembelian suatu produk. ${ }^{1}$

Dengan adanya garansi, nilai jual suatu produk akan bertambah dan keberadaan garansi tersebut dapat meningkatkan minat konsumen untuk membelinya. Suatu produk yang sejenis akan sangat berbeda dari segi harga bila yang satu memiliki garansi dan yang lain tidak. Harga produk yang tidak bergaransi biasanya lebih rendah dari yang bergaransi, namun demi keamanan dan terjaminnya kualitas suatu produk, konsumen biasanya memilih produk yang bergaransi. ${ }^{2}$

Garansi pada dasarnya merupakan salah satu daya tarik tersendiri bagi konsumen dalam jual beli. Garansi (warranty) adalah suatu perjanjian krontraktual yang mengharuskan produsen untuk memperbaiki atau mengganti produk yang mengalami kerusakan selama masa garansi. Baik konsumen maupun produsen mendapatkan manfaat dari garansi. Bagi konsumen, garansi melindungi dari membeli produk yang cacat, dan bagi produsen, garansi membatasi klaim yang tidak rasional dari konsumen. Produk yang dapat bertahan lama (seperti kendaraan bermotor, komputer, mesin/peralatan) umumnya dijual dengan garansi.

Disamping itu, produsen dapat memanfaatkan garansi sebagai alat promosi yang efektif karena produk dengan masa garansi yang lebih lama memberikan sinyal kepada konsumen bahwa produk tersebut memiliki kualitas yang lebih baik. ${ }^{3}$ Dalam upaya memikat hati konsumen para penjual atau produsen berusaha meningkatkan pelayanan dan fasilitas untuk kepuasan dan kesejahteraan para konsumen sehingga mereka mendapatkan barang yang sesuai dengan nilai tukar yang dikeluarkan. ${ }^{4}$

Lifetime warranty (garansi seumur hidup) adalah bentuk pernyataan dari produsen kepada konsumen yang berhubungan dengan adanya kompensasi untuk memperbaiki, mengganti part atau memperpanjang lamanya pemberian garansi apabila terjadi kerusakan atau kegagalan produk seumur hidup.

\footnotetext{
${ }^{1}$ Arie Siswanto, Hukum Persaingan Usaha, (Bogor : Ghalia Indonesia. 2008), h.14.

${ }^{2}$ Ibid.

${ }^{3}$ Bermawi P. Iskandar, Manajemen Garansi Produk dan Perkembangannya di Indonesia, Makalah tidak dipublikasikan, h. 1 .

${ }^{4}$ Ibid.
} 
Pada dasarnya layanan garansi seumur hidup (lifetime warranty) pada berbagai macam produk yang diberikan pelaku usaha kepada pembeli didasari hubungan perjanjian jual-beli, dan tergolong perjanjian baku atau standar, ${ }^{5}$ karena isinya telah dituangkan dalam bentuk klausa-klausa yang telah ditetapkan secara sepihak oleh produsen dan dituangkan dalam bentuk siap pakai. Dengan menggunakan perjanjian baku ini maka pihak produsen akan memperoleh efisiensi dalam penggunaan biaya, tenaga dan waktu.

Sesuai dengan Pasal 7 huruf e UU No 8 Tahun 1999 tentang Perlindungan Konsumen disebutkan bahwa pelaku usaha berkewajiban memberikan jaminan atau garansi atas barang yang diperdagangkan. Dan dalam KUHPerdata Buku II tentang Perikatan Pasal 1491 disebutkan bahwa: Penanggungan yang menjadi kewajiban penjual terhadap pembeli, adalah untuk menjamin 2 hal yaitu: pertama penguasaan barang yang dijual itu secara aman dan tenteram, kedua tiadanya cacat yang tersembunyi pada barang tersebut, atau yang sedemikian rupa sehingga menimbulkan alasan untuk pembatalan pembelian.

Selain itu, dalam Pasal 1504 juga disebutksn bahwa Penjual harus menanggung barang itu terhadap cacat yang tersembunyi ,yang sedemikian rupa sehingga barang itu tidak dapat digunakan untuk tujuan yang dimaksud, atau yang demikian mengurangi pemakaian, sehingga seandainya pembeli mengetahui cacat itu, ia sama sekali tidak akan membelinya atau tidak akan membelinya selain dengan harga yang kurang.

Hal pokok yang terkandung dalam lifetime warranty adalah pemenuhan tuntutan apabila terdapat para konsumen yang mengalami kerusakan barang selama masih dalam batas waktu perjanjian garansi yaitu selama produk tersebut masih diproduksi, dan bukan masa seumur hidup pembeli yang sering disalah tafsirkan oleh pembeli. Penyebab kerugian yang dialami pembeli adalah karena informasi mengenai garansi yang diberikan pelaku usaha baik lewat media masa atau elektronik tidak jelas dan kurang transparan baik pada masa pra transaksi maupun masa transaksi jual-beli, sehingga penafsiran pembeli terhadap makna yang tertera pada lebel produk berbeda dengan klausul garansi yang dibuat terpisah. Dan ketika pembeli ingin menuntut haknya, tuntutan tersebut tidak dapat dipenuhi secara keseluruhan oleh pihak penjual dikarenakan ketidakberdayaan dan kurangnya informasi yang jelas bagi para pembeli.

\footnotetext{
${ }^{5}$ Perjanjian baku dialih bahasakan dari istilah yang dikenal dalam bahasa Belanda yaitu "standard contract" atau "standard voorwaarden" yang di artikan sebagai konsep perjanjian tertulis yang disusun tanpa membicarakan isinya dan lazimya dtuangkan dalam sejumlah perjanjian, perjanjian baku isinya ditentukan oleh pihak yang kuat kedudukannya di dalam perjanjian itu. Pihak yang kuat dalam hal ini ialah pihak kreditur yang lazimnya mempunyai posisi kuat dibandingkan pihak debitur.
} 
Atas permasalahan-permasalahan yang menyangkut pelanggaran hak-hak konsumen itulah yang menjadi persoalan apakah pihak produsen benar benar memikirkan konsumen sehingga dapat dipertanggung-jawabkan tentang kebenaran produk barang dalam betuk jaminan mutu serta garansi yang ditawarkan ke masyarakat, serta sejauh mana tanggung jawab pelaku usaha terhadap konsumen yang dirugikan.

Dari uraian diatas, peneliti tertarik untuk mengkaji lebih dalam mengenai lifetime warranty ditinjau dari perspektif hukum ekonomi syari'ah.

\section{Pembahasan}

\section{Pengertian Garansi}

Kata garansi berasal dari Bahasa Inggris Guarantee yang berarti jaminan atau tanggungan. Dalam Kamus Besar Bahasa Indonesia, garansi mempunyai arti tanggungan. Sedangkan menurut Ensiklopedia Indonesia, garansi adalah bagian dari suatu perjanjian dalam jual beli, dimana penjual menanggung kebaikan atau keberesan barang yang dijual untuk jangka waktu yang ditentukan. ${ }^{6}$

Menurut Chairuman Pasaribu dan Suhrawardi K. Lubis, garansi adalah suatu kesepatakan dua pihak yang berupa tanggungan atau jaminan dari seorang penjual bahwa barang yang ia jual tersebut bebas dari kerusakan yang tidak diketahui sebelumnya oleh penjual dan lazimnya garansi atau jaminan ini punya jangka waktu tertentu (lazimnya 1 tahun, 2 tahun atau 3 tahun). ${ }^{7}$

Apabila barang tersebut mengalami kerusakan atau cacat, maka segala biaya perbaikannya di tanggung oleh penjual, sedang peraturan-peraturan garansi biasanya tertulis pada suatu surat garansi. ${ }^{8}$ Penjual akan memperbaiki terhadap kerusakan tersebut segala biaya perbaikan sepenuhnya ditanggung oleh penjual, atau sipenjual akan mengganti barang tersebut dengan yang sama nilainya. Hal tersebut sebagai ganti rugi terhadap kerusakan yang diderita oleh pembeli.

Garansi adalah perjanjian tertulis antara produsen dan konsumen meliputi spesifikasi produk, tanggung jawab pembeli, dan tindakan yang dilakukan oleh produsen apabila produk

\footnotetext{
${ }^{6}$ Ummy Salamah, Tinjauan Hukum Islam Terhadap Garansi dalam Jual Beli, Skripsi di UIN Sunan Kalijaga Yogyakarta, 2002, h. 41.

7 Chairuman Pasaribu dan Suhrawardi K. Lubis, Hukum Perjanjian dalam Islam, (Jakarta: Sinar Grafika, 1996), h. 43-44.

${ }^{8}$ Ummy Salamah, Tinjauan Hukum., h. 41.
} 
tidak bekerja sesuai dengan fungsinya. ${ }^{9}$ Garansi adalah bentuk pernyataan yang berhubungan dengan adanya kompensasi yang nantinya akan digunakan untuk memperbaiki, mengganti part atau memperpanjang lamanya pemberian garansi apabila terjadi kerusakan atau kegagalan produk selama masa garansi. ${ }^{10}$

Garansi adalah surat keterangan dari suatu produk bahwa pihak produsen (pelaku usaha) menjamin produk tersebut bebas dari kesalahan pekerja dan kegagalan bahan dalam jangka waktu tertentu. ${ }^{11}$ Dalam pelaksanaan transaksi garansi tersebut, si pembeli diberi surat, kartu garansi yang di dalamnya telah tercantum beberapa ketentuan yang di buat secara sepihak dan oleh penjual, sehingga si pembeli harus menerima ketentuan tersebut apabila hendak bertransaksi.

Garansi (Warranty) adalah suatu perjanjian kontraktual yang mengharuskan produsen untuk merektifikasi (memperbaiki atau mengganti) produk yang mengalami kerusakan selama masa garansi. Umumnya perbaikan produk rusak tidak dikenakan biaya kepada konsumen. ${ }^{12}$ Untuk garansi tertentu, rektifikasi mengharuskan pengembalian uang sebagian atau $100 \%$ dari harga jual kepada konsumen. Sangat sulit untuk mengetahui kapan tepatnya garansi pertama kali dikenalkan. Namun, jika garansi dipandang sebagai liabilitas produk (pertanggung-jawaban produsen), maka pada zaman Raja Babilonia, Hammurabi pada tahun 1800 sebelum Masehi, ditemukan undang-undang yang memberikan hukuman keras untuk craftmen yang terbukti melakukan kesalahan sehingga menghasilkan produk cacat. ${ }^{13}$

Berdasarkan definisi-definisi diatas, dapat penulis simpulkan bahwa garansi adalah suatu kesepakatan kontrak antara produsen dan konsumen yang mengharuskan proodusen untuk melakukan perbaikan terhadap produk yang mengalami kegagalan fungsional (karena kesalahan produksi) maupun karena sebab lain yang ditentukan dalam perjanjian selama periode tertentu.

\section{Macam-Macam Garansi}

Menurut M. Rofichul Nuril Abshor, dan Maria Anityasari jenis garansi dapat dikelompokkan ke dalam tiga kategori, yaitu garansi satu dimensi, garansi dua dimensi, dan garansi tambahan (extended warranty).

\footnotetext{
${ }^{9}$ M. Rofichul Nuril Abshor, dan Maria Anityasari, Analisis Perhitungan Biaya Garansi Untuk Produk Dengan Level Multiple Sub-Assemblies (Studi Kasus : Mesin Cuci LG 2 Tabung), dalam JURNAL TEKNIK POMITS, Vol. 1, No. 1, Surabaya: ITS, 2012, h. 3

${ }^{10}$ Ibid. $(8)$.

${ }^{11}$ Peraturan Menteri Perdagangan Republik Indonesia Nomor 19/M-DAG/PER/5/2009 Pasal 1 Angka

12 Adega Anggayasta, Analisis Pengaruh Produk Inti Dan Produk Peripheral terhadap Minat Beli Ulang Di Retronomic Boy Shop di Semarang, Skripsi di Universitas Diponegoro Semarang, 2011, h. 27

${ }^{13}$ Ibid.
} 


\section{a. Garansi Satu Dimensi}

Kebijakan garansi satu dimensi dikarakteristikkan oleh satu atribut, yaitu umur produk atau pemakaian. Sebagai contoh, sebuah TV digaransi selama satu tahun. Jenis garansi ini dibagi ke dalam dua kategori utama yaitu Free Replacement Warranty (FRW) dan Pro Rata Warranty (PRW).

Pada FRW, perbaikan produk yang mengalami kerusakan selama masa garansi tanpa dikenakan biaya kepada konsumen. Sedangkan, pada PRW, produk baru sebagai pengganti dari produk yang rusak dalam masa garansi diberikan dengan harga diskon. Atau konsumen harus mengeluarkan sejumlah uang (yang besarnya proporsional terhadap sisa masa garansi pada saat produk rusak) untuk mendapatkan produk baru.

FRW cocok diterapkan untuk produk yang dapat direparasi, misalnya komputer, sedangkan PRW tepat untuk produk yang tidak dapat direparasi, misalnya ban mobil. produsen akan mengembalikan

\section{b. Garansi Dua Dimensi}

Kebijakan garansi dua dimensi dikarakteristikkan oleh dua atribut (dimensi), di mana satu dimensi menjelaskan batas umur dan dimensi yang lainnya penggunaan. ${ }^{14}$ Garansi dua dimensi ditetapkan tidak hanya berdasarkan waktu pemakaian saja, melainkan juga jumlah pemakaian produk. Misalnya saja, kilometer untuk penggunaan kendaraan bermotor. ${ }^{15}$

Garansi dua dimensi banyak ditawarkan untuk produk otomotif, pesawat terbang, dan lain-lain. Sebagai contoh, sebuah mobil atau sepeda motor diberi garansi satu tahun atau $12.000 \mathrm{~km}$, tergantung yang mana yang berakhir lebih dahulu.

Garansi dua dimensi dikenal juga dengan garansi seumur hidup. Hal ini dikarenakan dalam garansi semumur hidup terdapat ketentuan yang mencakup dua atau lebih dimensi garansi. Biasanya, garansi seumur hidup ini berlaku sampai dengan perusahaan yang menjaminkan garansi tersebut terus memproduksi barang yang dimaksud. Pemberian garansinya juga harus memenuhi persyaratan yang sudah ditetapkan.

\footnotetext{
${ }^{14}$ Bermawi P. Iskandar, Manajemen Garansi..., h. 5

${ }^{15}$ Rofichul Nuril Abshor, dan Maria Anityasari, Analisis Perhitungan., h. 3.
} 


\section{c. Garansi Tambahan (Extended Warranty)}

Beberapa tahun terakhir ini, produsen menawarkan garansi tambahan (extended warranty). Sebagai contoh, banyak dealer yang menawarkan penjualan mobil dengan garansi tambahan setelah masa garansi dasar (base warranty) berakhir, misalnya perpanjangan waktu garansi satu tahun.

Hal ini pada umumnya berlaku untuk produk elektronik, di mana pembeli dapat mengajukan garansi tambahan, misalnya satu sampai dua tahun. Garansi dapat diperpanjang dengan melakukan kontrak kesepakatan baru tetapi konsumen harus mengeluarkan sejumlah uang atau membeli jasa ini.

Garansi tambahan ini merupakan pilihan bagi konsumen untuk memperpanjang atau tidak, atau sifatnya tidak diwajibkan. Garansi tambahan dapat ditawarkan oleh produsen maupun pihak ketiga. Garansi tambahan mirip dengan service contract di mana ada pihak luar (produsen atau pihak ketiga) yang sanggup merawat produk untuk periode tertentu berdasarkan kontrak dengan pemilik produk. $^{16}$

Bagi produsen, garansi tambahan memberikan layanan purna jual kepada konsumen yang tidak terbatas pada masa garansi tetapi juga di luar garansi. Layanan purna jual yang baik akan menciptakan kepuasan pelanggan (customer satisfication), sehingga akan menambah loyalitas konsumen terhadap produk. Dan ini dapat digunakan sebagai alat promosi yang efektif untuk memenangkan persaingan dengan produk yang sejenis.

Penawaran ongkos yang relatif murah dan garansi tambahan yang menguntungkan konsumen membuat jasa garansi tambahan menjadi suatu produk yang menarik bagi konsumen. Dan ini membuka peluang bisnis untuk memberikan jasa garansi tambahan oleh pihak ketiga.

\section{Konsep Lifetime Warranty sebagai Jaminan dalam Jual Beli Produk}

Lifetime warranty adalah salah satu keunggulan tersendiri bagi suatu produk. Hal ini dikarenakan konsumen dapat menukar produk lifetime warranty dengan yang baru apabila produk tersebut mengalami kerusakan. Hanya saja, ada beberapa ketentuan yang diterapkan oleh perusahaan pemberi garansi terhadap penggantian produk lifetime warranty yang mengalami kerusakan.

\footnotetext{
${ }^{16}$ Bermawi P. Iskandar, Manajemen Garansi., h. 5-6
} 
Tujuan pemberian lifetime warranty diantaranya adalah memberikan keyakinan kepada konsumen bahwa produk yang ditawarkan benar-benar produk yang berkualitas baik. Selain itu, pemberian lifetime warranty juga bertujuan untuk memberikan kepuasan terhadap konsumen atas produk yang diberikan.

Produk-produk lifetime warranty pada umumnya adalah produk-produk yang mampu bertahan lama dan memiliki kualitas yang baik. Sehingga, sangat jarang sekali mengalami kerusakan. Hanya saja, permasalahan konsumen yang sering muncul adalah konsumen sering merasa dirugikan, karena ketika konsumen mengajukan klaim garansi, ia tidak bisa mendapatkan penggantian produk yang diajukan. Hal ini dikarenakan, klaim yang diajukan oleh konsumen tidak termasuk kedalam aturan pemberian garansi.

Setiap produsen memiliki ketentuan-ketentuan tersendiri dalam memberikan garansi. Namun, semuanya memiliki kesamaan dalam memberikan ketentuan garansi. Produsen samasama berupaya memberikan rasa nyaman kepada konsumen yang membeli produk dan samasama memberikan keyakinan bahwa produk yang diberikan adalah produk yang aman dan benar-benar baik.

Pada hakikatnya, dalam ketentuan-ketentuan garansi ada beberapa pengecualian terhadap pemberian garansi. Pengecualian ini pada umumnya berupa akibat penggunaan produk yang salah. Pada dasarnya jaminan produk adalah bagian dari hukum jaminan. Hukum jaminan sendiri meliputi dua pengertian yaitu hukum jaminan kebendaan dan hukum jaminan perorangan. Jaminan kebendaan meliputi piutang-piutang yang diistimewakan, gadai dan hipotek. Sedangkan jaminan perorangan meliputi penanggungan utang (borgtoch) termasuk juga perikatan tanggung menanggung dan perjanjian garansi. Jaminan produk yang pada dasarnya bila dikaitkan dengan Kitab Undang-Undang Hukum Perdata merupakan bagian dari hukum jaminan. ${ }^{17}$

Dalam Kitab Undang-Undang Hukum Perdata garansi termasuk pada bagian jaminan perorangan, yang diatur pada buku III Kitab Undang-Undang Hukum Perdata. ${ }^{18}$ Garansi adalah bagian dari suatu perjanjian, maka termasuk didalam buku ke III Kitab UndangUndang Hukum Perdata mengenai perikatan (van verbintenissen). Perjanjian garansi diatur dalam Pasal 1316 Kitab Undang-Undang Hukum Perdata.

Garansi adalah surat keterangan dari suatu produk bahwa pihak produsen (pelaku usaha) menjamin produk tersebut bebas dari kesalahan pekerja dan kegagalan bahan dalam

\footnotetext{
${ }^{17}$ Rachmadi, Hukum Jaminan Keperdataan,( Jakarta: Sinar Grafika, 2009), h. 24-25

${ }^{18}$ Ibid, h.23-24
} 
jangka waktu tertentu. Surat tersebut sering disebut dengan kartu garansi ataupun kartu jaminan. Kartu jaminan/garansi adalah kartu yang menyatakan adanya jaminan ketersediaan suku cadang serta fasilitas dan pelayanan purna jual produk telematika dan elektronika. Definisi kartu jaminan/garansi diatur dalam Pasal 1 Angka (8) Peraturan Menteri Perdagangan Republik Indonesia Nomor 19/M-DAG/PER/5/2009 Tentang Pendaftaran Petunjuk Penggunaan (manual) Dan Kartu Jaminan/Garansi Purna Jual Dalam Bahasa Indonesia.

Garansi ini sangat berharga sebab dengan adanya garansi, selain jaminan kualitas produk tersebut juga mempengaruhi harga jual dan minat pembeli suatu produk. Dengan adanya garansi, nilai jual suatu produk akan bertambah dan keberadaan garansi tersebut dapat meningkatkan minat konsumen untuk membelinya. Suatu produk yang sejenis akan sangat berbeda dari segi harga bila yang satu memilki garansi dan yang lain tidak. Harga produk yang tidak bergaransi biasanya lebih rendah dari yang bergaransi, namun demi keamanan dan terjaminnya kualitas suatu produk, konsumen biasanya memilih produk yang bergaransi.

Jaminan kualitas produk yang ditawarkan oleh pelaku usaha merupakan salah satu faktor yang dapat mempengaruhi pilihan konsumen. Umumnya jaminan kualitas dinyatakan secara tegas dalam proses penawaran maupun pada perjanjian jual beli. Ada dua macam jaminan dalam praktik jual beli produk, yaitu:

\section{Express Warranty (jaminan secara tegas)}

Express Warranty adalah suatu jaminan atas kualitas produk, baik dinyatakan secara lisan maupun tertulis. Adanya express warranty ini, berarti produsen sebagai pihak yang menghasilkan barang (produk) dan juga penjual sebagai pihak yang menyalurkan barang atau produk dari produsen atau pembeli bertanggung jawab untuk melaksanakan kewajibannya terhadap adanya kekurangan atau kerusakan dalam produk yang dipasarkan. Dalam hal demikian, konsumen dapat mengajukan tuntutannya berdasarkan adanya wanprestasi.

\section{Implied Warranty}

Implied warranty adalah suatu jaminan yang dipaksakan oleh undang-undang atau hukum, sebagai akibat otomatis dari penjualan barang-barang dalam keadaan tertentu. Jadi, dengan implied warranty dianggap bahwa jaminan ini selalu mengikuti barang yang dijual, kecuali dinyatakan lain. Pelayanan garansi merupakan bentuk penanggungan yang menjadi kewajiban penjual kepada pembeli terhadap cacat-cacat 
barang yang tersembunyi. Selain itu garansi juga sebagai salah satu upaya untuk melindungi kepuasan konsumen. ${ }^{19}$

Dalam perkembangan dunia perdagangan dewasa ini, garansi merupakan kepentingan konsumen yang sangat vital, sehingga garansi dalam jual beli memiliki fungsi sebagai penjaminan apabila dalam masa-masa garansi ditemukan cacat-cacat tersembunyi oleh pembeli dan pengikat terhadap pihak penjual untuk memenuhi prestasi (kewajiban) yang telah disepakati bersama dengan pembeli.

Mengenai ketentuan-ketentuan yang merupakan kesepakatan antara kedua pihak dalam perjanjian garansi jual beli biasanya tercantum dalam surat garansi yang diberikan kepada pembeli, antara lain berupa jenis cacat yang termasuk dalam penjaminan masa garansi dan sebagainya. Ketentuan-ketentuan tersebut biasanya dibuat oleh pihak penjual sebelum transaksi sehingga pembeli tidak ikut andil dalam memutuskan ketentuan-ketentuan itu. Pembeli tidak berhak untuk menawar syarat-syarat yang telah ditentukan oleh penjual. Dalam perjanjian ini, pembeli hanya dihadapkan pada dua pilihan yaitu:

1. Jika pembeli ingin melakukan transaksi, maka harus sepakat dengan ketentuanketentuan tersebut.

2. Jika pembeli tidak sepakat dengan ketentuan-ketentuan tersebut, maka transaksi tidak akan terjadi. ${ }^{20}$

Banyak produk yang mengandung resiko tertentu untuk konsumen, khususnya resiko untuk keselamatan dan kesehatan. Oleh karenanya konsumen berhak mendapatkan langkah preventif dari pelaku usaha untuk meminimalisasi resiko yang mungkin terjadi sebagai perwujudan dari the right to safety. Konsumen berhak mengetahui segala informasi yang relevan mengenai produk yang dibelinya, baik apa sesungguhnya produk tersebut, maupun bagaimana cara memakainya, maupunn juga resiko yang menyertai pemakainya.

Jika suatu produk diberi garansi untuk jangka waktu tertentu, segala syarat dan konsekuensinya harus dijelaskan secara lengkap. Semua informasi yang disebut pada label sebuah produk (baik yang tertera langsung pada produk maupun dalam lembar promosi) harus menunjukkan keadaan sesungguhnya dari produk tersebut. Sistem ekonomi pasar bebas konsumen berhak untuk memilih antara berbagai macam produk dan jasa yan ditawarkan. Kualitas dan harga produk bisa berbeda. Konsumen berhak untuk membandingkannya

\footnotetext{
${ }^{19}$ Andrian Sutedi, Tanggung Jawab Produk dalam Hukum Perlindungan Konsumen, (Bogor: Ghalia Indonesia, 2008), h. 75

${ }^{20}$ Ibid.
} 
sebelum memutuskan untuk membeli. Hak yang dimiliki konsumen merupakan hak legal yang dapat dituntut di muka pengadilan. ${ }^{21}$

Pemberian garansi merupakan kepentingan konsumen yang sangat vital di era persaingan terbuka ini. Meningkatnya jumlah supply barang sejenis dengan berbagai macam kualifikasi mewajibkan konsumen untuk lebih cerdas dalam menentukan pilihan produk dan jasa. Pemberian garansi kepada konsumen (pembeli) pada prinsipnya sejalan dengan salah satu tujuan dasar UUPK yaitu mengangkat harkat dan martabat konsumen dengan cara menghindarkannya dari ekses negatif pemakaian barang dan jasa.

Keberadaan garansi ialah untuk memberikan perlindungan kepada konsumen atas pemakaian produk yang dibeli olehnya. Berdasarkan Pasal 7 huruf e pelaku usaha wajib memberi garansi atas barang yang dibuat dan diperdagangkan. Garansi memberikan gambaran kepada konsumen bahwa pelaku usaha menjamin bahwa produk yang dijual olehnya merupakan produk yang berkualitas. Pada dasarnya, garansi memberikan kesempatan kepada konsumen untuk memperoleh ganti kerugian atas kerusakan yang muncul pada produk tersebut dalam masa garansi.

Konsumen melalui garansi, mendapatkan perlindungan hukum untuk menikmati pemakaian produk secara nyaman dan aman. Terhadap kerusakan yang dialami oleh produk pada masa garansi, konsumen dapat menuntut itikad baik dari pelaku usaha untuk melakukan perbaikan atas kerusakan tersebut sepanjang kerusakan tersebut bukan merupakan kerusakan akibat hal-hal yang dikecualikan dalam UUPK.

Dapat disimpulkan, garansi merupakan layanan yang diberikan pelaku usaha yang dapat memberikan jaminan rasa aman kepada konsumen atas pamakaian produk yang dibelinya, selain itu garansi juga merupakan pertanggungjawaban hukum bagi pelaku usaha untuk memberikan layanan ganti rugi kepada konsumen atas kerusakan yang dialami oleh produk selama masa garansi, sepanjang tidak disebabkan oleh hal-hal yang dikecualikan dalam UUPK.

\section{Lifetime Warranty Ditinjau dari Perspektif Al-Quran dan Hadits}

Lifetime warranty merupakan salah satu pelayanan produsen kepada konsumen yang sama dengan khiyar aib. Asal mula pemberian lifetime warranty adalah jual beli. Allah berfirman dalam surah An-Nisa ayat 29:

\footnotetext{
${ }^{21}$ Ibid.
} 

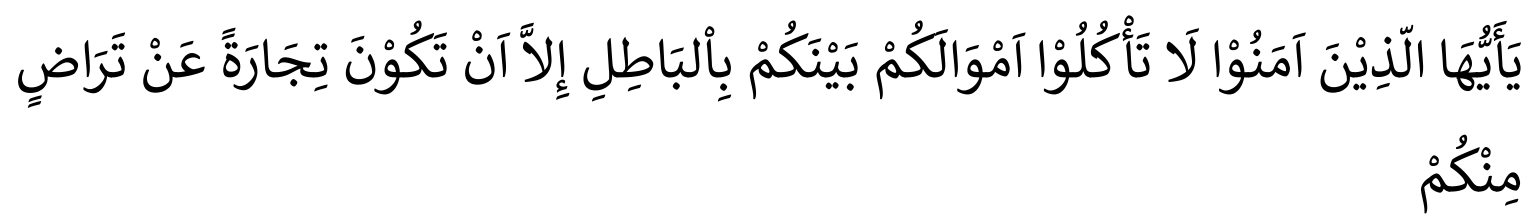

Artinya : "Hai orang-orang yang beriman, janglah kalian saling memakan harta sesamamu dengan jalan yang batil kecuali dengan jalan perniagaan berlaku dengan suka sama suka diantara kamu (an-Nisa': 29) ${ }^{22}$

Menurut Ibnu Katsir, Allah Ta'ala melarang hamba-hamba-Nya yang beriman memakan harta sesama mereka secara batil, yakni melalui aneka jenis usaha yang tidak disyari'atkan seperti riba dan judi ${ }^{23}$ serta beberapa jenis tipu muslihat yang sejalan dengan kedua cara itu, walaupun sudah jelas pelarangannya dalam hukum syara', seperti yang telah dijelaskan Allah bahwa orang yang melakukan muslihat itu dimaksudkan untuk mendapatkan riba. $^{24}$

Ibnu Jarir meriwayatkan dari Ibnu Abbas ihwal seseorang yang membeli pakaian dari orang lain. Penjual berkata, "Jika kamu suka, ambillah. Jika kamu tidak suka, kembalikanlah disertai satu dirham." Ibnu Abbas berkata, "Itulah praktik yang karenanya Allah berfirman, 'Hai orang-orang yang beriman, janganlah aтu memakan harta sesama kamu dengan batil." Sehubungan dengan ayat itu, Ibnu Abi Hatim meriwayatkan dari Al-qamah, dari Abdullah, dia berkata. "Ayat itu muhkam ia tidak dinasakh dan menasakh hingga hari kiamat." Allah Ta'ala berfirman, "Kecuali dengan perdagangan secara suka sama suka di antara kamu." Maksudnya, janganlah kamu melakukan praktik-praktik yang diharamkan dalam memperoleh harta kekayaan, namun harus melalui perdagangan yang disyari'atkan dan berdasarkan kerelaan antara penjual dan pembeli. Kerjakanlah perdagangan yang demikian dan jadikanlah sebagai sarana untuk memperoleh harta kekayaan. ${ }^{25}$

Mujtahid menafsirkan penggalan ayat ini dengan: jual-beli atau pemberian yang dilakukan oleh seseorang kepada orang ain. Ibnu Jrir meriwayatkan dari Maimun bin Mahran, dia berkata bahwa Rasulullah SAW bersabda, "Jual beli harus dilakukan secara suka sama suka; khiyar dilakukan stelah akad. Seorang Muslim tidak boleh menipu Muslim yang lain.” Puncak dari sikap suka sama suka adalah penetapan khiyar majelis, sebagaimana ditegaskan

${ }^{22}$ QS. An-Nisa (4): 29.

${ }^{23}$ Berbagai jenis riba banyak dilakukan dan dikenal pada zaman kita sekarang, misalnya menjual secara kredit atau menjual satu barang dengan dua jenis patokan. Contohnya jika membeli dengan kontan harganya 10 dirham, jika bertempo 12 dirham. Demikian pula dengan undian yang merupakan judi.

${ }^{24}$ Muhammad Nasib Ar-Rifa'i, TaisiruAl-Aliyyil Qadir Li Ikhtishari, Penerjemah: Syihabuddin, (Jakarta: Gema Insani Press, 2012), h. 523.

${ }^{25}$ Ibid, h. 524. 
dalam ash-Shahihain bahwa Rasulullah SAW bersabda, 'Penjual dan Pembeli masih memiliki pilihan selagi keduanya belum berpisah."26

Pandangan ini dipegang oleh Ahmad, Syafi'i, para pengkut keduanya, dan jumhur ulama salaf dan khalaf. Dari situ, disyari'atkan khiyar syarat, setelah akad hingga tiga hari guna mengetahui kondisi barang yang diperjualbelikan; atau hingga satu tahun jika keduanya berada di satu kampung; atau hingga waktu tertentu. Pendapat ini dikenal berasal dari Malik rahimullah. $^{27}$

Dalam ayat ini terdapat kata "suka sama suka diantara kamu", ini menunjukkan juga kebolehan Lifetime warranty dengan syarat penjual dan pembeli sama-sama ridho dan tidak merasa terpaksa. Dalam sebuah hadits juga dinyatakan:

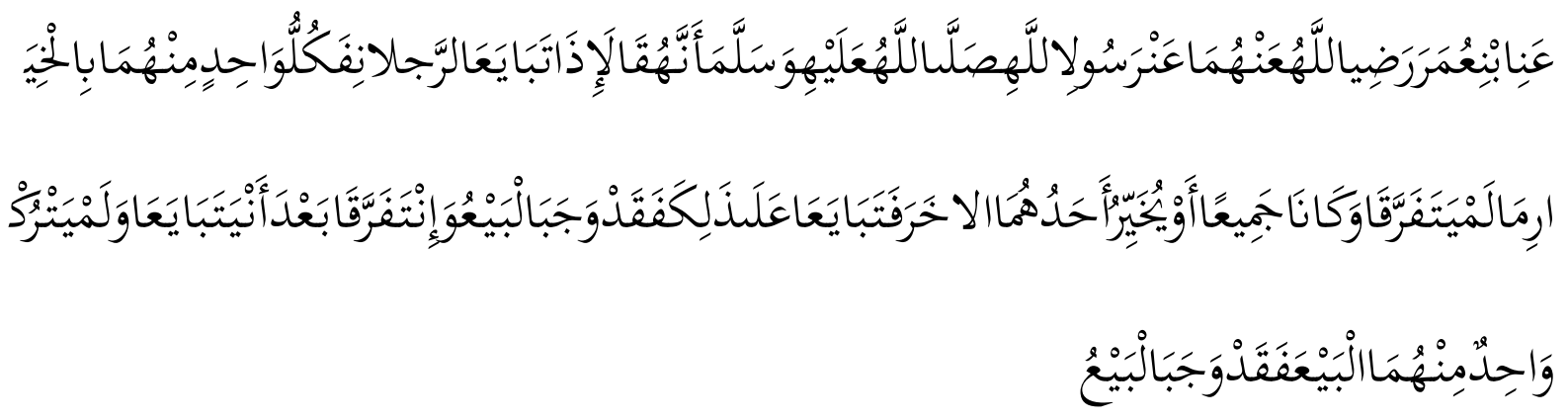

Artinya: "Dari Ibn 'Umar, Rasulullah Saw. bersabda: apabila dua pihak melakukan transaksi jual beli, maka masing-masing mendapatkan haknya untuk meneruskan atau membatalkan jual beli selama keduanya belum berpisah dan keduanya selalu bersama. Atau salah satu dari keduanya mengambil hak khiyar (syarat) lalu melakukan jual beli berdasarkan khiyar syarat tersebut, maka terjadilah jual beli. Jika keduanya berpisah setelah terjadinya jual beli dan salah satunya tidak meninggalkan sesuatu (pesan) maka secara hukum jual beli telah terjadi," (HR. Bukhori Muslim). ${ }^{28}$

Jual beli membawa konsekwensi hukum berpindahnya hak kepemilikan suatu benda/barang dari pihak penjual kepada pihak pembeli dengan memberikan perimbangan harga dan ketentuan-ketentuan tertentu (jika ada) yang telah disepakati. Oleh sebab itu, ada hak khusus yang diberikan oleh Islam kepada pihak-pihak yang melakukan transaksi. Ada

\footnotetext{
${ }^{26}$ Ibid.

${ }^{27}$ Ibid.

28 Muhammad Fuad Abdul Baqi, Al-lu'lu' wal Marjanu Fima Itta Faqa'alaihi Asy-Syaykhani AlBukhariyyubwa Muslimun, Penerjemah; Muhammad Suhadi, dkk, dalam Mutiara Hadiths Sahih Bukhari Muslim, (Jakarta:Ummul Qura, 2012), h. 273.
} 
hak khiyar baik bagi penjual mau pun pembeli selama proses jual beli masih berlangsung dan belum mempunyai kekuatan hukum yang tetap. ${ }^{29}$

Adanya jaminan hak khiyar ini dapat memberikan peluang kepada penjual dan pembeli untuk melanjutkan transaksi jual beli atau tidak, sehingga prinsip dasar suka sama suka dalam transaksi benar-benar terwujud.

Dalam hadis yang disebutkan di awal juga mengatur tentang khiyar syarat. Jual beli dilakukan berdasarkan syarat yang sudah disepakati. Dalam khiyar syarat ini meskipun terjadi perpisahan badan, namun hak khiyarnya masih tetap ada selama persyaratan yang ditetapkan masih ada. Dalam khiyar syarat, pembeli atau penjual hanya dapat menggunakan hak khiyarnya sesuai dengan syarat atau komitmen yang sudah disepakati keduanya. ${ }^{30}$

Sangat jelas aturan Islam menetapkan adanya hak khiyar baik bagi penjual atau pun pembeli sebagai realisasi dari adanya unsur suka sama suka dan tidak ada keterpaksaan baik tentang kualitas, kuantitas, ukuran atau pun harga yang disepekati oleh kedua belah pihak. Pihak penjual dijamin dari kekeliruannya dalam memberikan harga untuk suatu barang yang mungkin beda jenis ukuran dan kualitasnya. Begitu juga, khiyar menjamin pembeli yang mungkin saja keliru dalam memilih jenis, ukuran, kualitas dengan harga yang juga tidak pantas.

Dalam hadis yang menjadi bahasan juga diatur tentang khiyar aib (cacat). Pembeli mempunyai hak untuk khiyar jika terdapat aib pada objek yang diperjualbelikan. Lifetime warranty merupakan salah satu wujud dari khiyar aib. Lifetime warranty memberikan kepastian kepada konsumen mengenai penggantian produk yang telah dibeli oleh konsumen. Secara implisit, lifetime warranty merupakan pemberian hak khiyar dari penjual kepada pembeli yang justru jarang diberikan oleh penjual lain.

Hal yang tidak diperbolehkan dalam jual beli pada dasarnya adalah bersumpah. Ketika penjual menawarkan barang daganganya kepada pembeli, termasuk di dalamnya penjual tersebut menawarkan lifetime warranty, maka ini tidak diperbolehkan. Hal ini sesuai dengan sabda Rasulullah SAW yang artinya: "Jauhilah olehmu banyak bersumpah dalam menjual barang, karena sesungguhnya sumpah itu dapat mempercepat lakunya barang namun menghilangkan berkahnya," (HR. Bukhari Muslim). ${ }^{31}$

Menurut Abdurrahman al-Jaziri, status khiyar dalam pandangan ulama Fiqh adalah disyariatkan atau dibolehkan, karena suatu keperluan yang mendesak dalam

\footnotetext{
${ }^{29}$ Enizar, Hadis Ekonomi, (Jakarta: Raja Grafindo Persada, 2013), h. 145

${ }^{30}$ Ibid.

${ }^{31}$ Muslich Sabir, Terjemah Riyadhus Shalihin II, (Semarang: Toha Karya, 2004), h. 307.
} 
mempertimbangkan kemaslahatan masing-masing pihak yang melakukan transaksi. ${ }^{32}$ Ini menunjukkan bahwa pemberian hak khiyar oleh penjual, khususnya dalam hal ini adalah Lifetime warranty juga diperbolehkan.

\section{Relevansi Lifetime Warranty dengan Khiyar Aib}

Lifetime warranty merupakan bentuk penanggungan yang menjadi kewajiban penjual kepada pembeli terhadap cacat-cacat yang ada pada barang. Selain itu garansi juga sebagai salah satu upaya untuk melindungi kepuasan konsumen. Lifetime warranty memiliki unsurunsur dan prinsip-prinsip yang sama dengan khiyar aib yang disyari'atkan. Dalam lifetime warranty terdaapat beberapa prinsip, diantaranya yaitu :

a. Prinsip Ar-Rhidha, yakni segala transaksi ang dilakukan haruslah adas dasar kerelaan masing-masing pihak (freedom contract).

b. Prinsip persaingan sehat (fair competition), yakni mekanisme pasar harus dilakukan dengan sehat, tidak boleh ada penimbunan (ikhtikar) atau monopoli.

c. Prinsip kejujuran, yakni prinsip yang sangat penting dalam ajaran Islam, sebab Islam melarang segala bentuk penipuan.

d. Prinsip keterbukaan (transparency) dan keadilan (justice), yakni setiap transaksi yang dilakukan dituntut untuk berlaku benar dalam pengungkapan kehendak dan keadaan yang sesungguhnya. ${ }^{33} /$

Perkembangan jual beli dalam aktivitas ekonomi syari'ah semakin pesat dan membutuhkan inovasi baru untuk menarik dan memberikan kepuasan konsumen. Dalam hal ini, lifetime warranty merupakan salah satu pelayanan garansi yang dapat disamakan dengan khiyar aib karena keduanya merupakan bentuk pengembalian barang apabila terdapat cacat/kerusakan.

Prinsip suatu akad adalah keralaan para pihak yang mengadakan akad dan dengan kerelaan tersebut berarti para pihak telah rela terhadap konsekuensi yang akan ditimbulkannya, dalam hal ini berupa ketentuan-ketentuan yang ada pada lifetime warranty, termasuk ketetapan waktu berlakunya garansi. Konsumen yang membeli produk lifetime warranty berarti telah sepakat dengan ketentuan-ketentuan yang ada dan ketentuan tersebut tidak bertentangan denga syara', dalam arti ketika pembeli bersedia (rela) terhadap ketentuan tersebut, selanjutnya membeli produk tersebut, berarti pembeli telah sepakat terhadap apa

\footnotetext{
${ }^{32}$ Amir Syarifuddin, Fiqh Muamalah, (Jakarta: Pranada Media, 2005), ke-1, h. 213.

${ }^{33}$ Anonim, Prinsip Jual Beli, Diakses Melalui Laman: http://dinulIslam.blogspot.com/2013/02/prinsip-jualbeli.html Pada Minggu 15 Mei 2016 Pukul 07.28 WIB.
} 
yang ditawarkan oleh penjual pada waktu itu juga dan jika pembeli tidak bersedia dengan ketentuan tersebut, maka akad tidak berlangsung.

Dalam perjanjian garansi jual beli, prestasi (kewajiban) yang harus dilakukan oleh penjual adalah berupa menanggung segala cacat yang tersembunyi pada barang yang diperdagangkan. Jadi dalam hal ini, cacat tersembunyi merupakan hal yang sangat penting. Yang dimaksud cacat tersembunyi adalah cacat yang tidak mudah dilihat oleh pembeli. ${ }^{34}$

Apabila cacat tersebut telah diketahui sebelumnya oleh pembeli, maka penjual tidak bertanggung jawab terhadap cacat yang kelihatan tersebut, karena dapat dianggap bahwa pembeli menerima adanya cacat dengan harga yang disesuaikan dengan adanya cacat. Hal ini sebagaimana yang tercantum dalam KUHPdt pasal 1505, bahwa penjual tidak diwajibkan menanggung terhadap cacat yang kelihatan yang telah diketahui oleh pembeli. Dengan demikian, dalam perjanjian garansi jual beli, penjual memiliki kewajiban untuk menanggung cacat-cacat barang yang tersembunyi dan tidak diketahui sebelum adanya transaksi. ${ }^{35}$

Lifetime warranty merupakan jenis fasilitas dari penjual yang sangat bermanfaat bagi semua pihak, baik bagi pemberi garansi (penjual) sendiri maupun bagi penerimanya (pembeli) serta bermanfaat bagi masyarakat pada umumnya, tidak menimbulkan bagi orang lain, melainkan merupakan tindakan saling tolong menolong dalam kewajiban yang sangat dianjurkan oleh agama.

Lifetime warranty dalam jual beli sebagaimana yang berjalan sekarang ini memang tidak dikenal pada masa Rasulullah SAW, namun bukan berarti terlarang, karena pada dasarnya semua bentuk muamalat adalah boleh.

Dalam Islam, manusia juga diberi kebebasan untuk mengatur kehidupannya sendiri yang dinamis dan lebih bermanfaat, sepanjang aturan yang dibuatnya tersebut tidak bertentangan dengan ketentuan syari'at Islam termasuk melakukan berbagai macam bentuk muamalat dalam memenuhi kebutuhan hidupnya. Apabila ada suatu kelaziman yang diterima

\footnotetext{
${ }^{34}$ Cacat tersembunyi adalah cacat yang membuat barang itu tidak sanggup untuk dipakai semestinya, sehigga seandainya pembeli mengetahui cacat itu, ia sama sekali tidak akan membeli barang itu atau membelinya dengan harga yang murah. Ibid, h.44. Lihat juga pasal 1504 KUHPdt.

${ }^{35}$ Hak dan kewajiban antara penjual dan pembeli diantara adalah:pembeli berhak untuk memilih barang, serta mendapatkan barang tersebut sesuai dengan nilai tukar dan kondisi serta jaminan yang dijanjikan; pembeli berhak atas informasi yang benar, jelas, jujur mengenai kondisi dan jaminan barang; pembeli berhak untuk mendapatkan kompensasi, ganti rugi, atau penggantian apabila barang yang diterima tidak sesuai dengan perjanjian atau tidak sebagaimana mestinya; penjual wajib memberikan informasi yang benar, mengenai kondisi dan jaminan barang serta memberikan penjelasan penggunaan, perbaikan dan pemeliharaan. penjual wajib menjamin mutu barang yang diperdagangkan berdasarkan ketentuan standar mutu barang yang berlaku; penjual berkewajiban untuk memberi kesempatan kepada konsumen untuk menguji atau mencoba barang tertentu serta memberi jaminan garansi atas barang yang diperdagangkan; serta penjual wajib memberikan kompensasi, ganti rugi dan penggantian apabila barang yang diterima atau dimanfaatkan tidak sesuai dengan perjanjian. Lihat Undang-Undang No.8 Tahun 1999 tentang Perlindungan Konsumen.
} 
ditengah-tengah masyarakat dan tidak bertentangan dengan syari'at, maka kelaziman tersebut bisa dijadikan hukum. Hal ini sesuai dengan kaidah fiqih yang berbunyi "Adat kebiasaan yang diakui dapat dijadikan sebagai landasan hukum". Dengan kata lain, bahwa pelayanan garansi jual beli sudah sesuai dengan prinsip-prinsip hukum muamalat sebagaimana yang diungkapkan oleh Ahmad Azhar Basyir yaitu:

"Pada dasarnya segala bentuk muamalat adalah mubah, kecuali yang ditentukan lain oleh al-Qur'an dan hadits. Muamalat dilaksanakan atas dasar suka sama suka, tanpa ada unsur paksaan. Muamalat juga dilakukan atas dasar pertimbagan mendatangkan manfaat dan menghindarkan kemudaratan. Muamalat dilakukan dengan memelihara nilai keadilan." 36

Ketentuan dan mekanisme yang terdapat pada lifetime warranty ditinjau segi maslahah telah memenuhi syarat maslahah mursalah sebagai dasar dalam menetapkan hukum Islam, yaitu mengandung kemaslahatan, sejalan dengan maksud pembentukan hukum Islam, tidak ditunjukkan oleh dalil yang membenarkan atau membatalkannya, dan merupakan bentuk muamalah, sehingga akad tersebut dapat dinyatakan sah dan dapat dilaksanakan akibat hukumnya, serta mengikat bagi para pihak.

Ketentuan dan mekanisme tersebut juga telah sesuai dengan prinsip-prinsip muamalah yaitu atas dasar kerelaan para pihak dan mendatangkan kemaslahatan serta menghindari adanya kerugian dan penindasan terhadap hak-hak konsumen, seperti pada cacat atau kerusakan yang diakibatkan oleh kesalahan produksi yang diakibatkan langsung oleh kelalain produsen akan mendapatkan ganti rugi. Sama halnya dengan kerusakan karena faktor alami yaitu terjadinya proses pemakaian yang panjang sehingga mengakibatkan penurunan kualitas produk atau kerusakan, produsen tetap memberikan jaminan atas kerusakan tersebut, meskipun belum tentu diakibatkan oleh kelalaiannya, dengan maksud untuk menghidari adanya kemungkinan kerusakan tersebut terjadi karena kelalaiannya secara tidak langsung.

Lifetime warranty merupakan perjanjian yang berupa penjaminan terhadap cacat yang tersembunyi oleh penjual kepada pembeli dalam jangka waktu tertentu, oleh sebab itu dalam hukum Islam pembeli berhak menggunakan hak khiyarnya apabila terdapat cacat yang tidak diketahui sebelum transaksi oleh penjual dan pembeli. Hak khiyar yang dimaksud dalam hal ini adalah khiyar aib (cacat).

Seperti yang sudah dijelaskan sebelumnya, khiyar aib adalah hak untuk memilih antara meneruskan atau membatalkan akad apabila ditemui cacat pada barang yang dipejual belikan. Tetapi hak khiyar tidak berlaku pada cacat yang telah diketahui sebelum terjadi jual beli.

\footnotetext{
${ }^{36}$ Ibid, h. 49.
} 
Namun demikian Islam melarang jual beli yang mengandung cacat, tetapi berusaha disembunyikan untuk mendapatkan harga dan keuntungan yang tinggi.

Pelaksanaan terhadap perjanjian usaha terkadang menemui berbagai cacat yang bisa menghilangkan keridhaan satu pihak, atau membuat cacat objek perjanjian, sehingga pihak yang merasa dirugikan bisa membatalkan perjanjian tersebut. ${ }^{37}$

Adapun bentuk penjaminan terhadap cacat tersembunyi dalam perjanjian lifetime warranty berupa perjanjian mengganti barang dengan yang baru, tidak lepas dari unsur keadilan, sehingga dalam hal ini tidak ada pihak yang merasa dirugikan dan benar-benar berdasarkan pada kerelaan hati pihak-pihak yang bersangkutan yang merupakan syarat utama dalam muamalat, seperti juga ditetapkannya hak khiyar aib yaitu hak untuk memilih melanjutkanatau membatalkan karena adanya cacat dengan tujuan untuk menjamin agar akad yang diadakan benar-benar terjadi atas kerelaan penuh pihak-pihak yang bersangkutan yang merupakan asas bagi sahnya suatu akad.

Dalam perjanjian garansi jual beli diatur bahwa penjual berkewajiban untuk memenuhi pelayanan garansi yang sudah ditentukan, sebagaimana yang termaktub dalam pasal 25 (1) Undang-Undang No.8 tahun 1999 tentang perlindungan konsumen dan dalam pasal 1338 KUHPdt yang berbunyi: "Semua perjanjian yang telah dibuat, secara sah adalah mengikat para pihak yang membuatnya sebagai undang-undang diantara mereka." 38

Hal ini senada dengan hukum Islam yang menyatakan bahwa seorang muslim berkewajiban untuk memenuhi janji yang telah mereka sepakati, karena janji tersebut akan dimintai pertanggung jawabannya. Dengan demikian sebagai bentuk perjanjian penanggungan sebuah kewajiban, garansi jual beli membawa konsekuensi logis pada adanya tuntutan pembayaran atau pemenuhan terhadap kewajiban tersebut oleh pembeli apabila penjual ternyata tidak memenuhi kewajibannya sesuai dengan kesepakatan yang telah dibuat dalam perjanjian, serta tuntutan ganti rugi atas kerugian yang diderita oleh pembeli. ${ }^{39}$

Apabila terjadi perubahan kondisi mendatang pada masa terjadinya perjanjian secara drastis, seperti kenaikan nilai mata uang, kenaikan bahan-bahan pokok, sehingga pelaksanaan perjanjian usaha tersebut sesuai perjanjian dapat menimbulkan kerugian besar bagi pihak yang menjaga komitmen yang harus ia tanggung, maka pihak hakim boleh merubah hak-hak dan komitmen bila terjadi konflik, sehingga kerugian ditanggung secara bersama oleh kedua belah pihak.

\footnotetext{
${ }^{37}$ Al-Mushlih, Abdullah dan Shalah ash-Shawi, Ekonomi Islam: Hukum-Hukum Umum Dalam Perjanjian Usaha. Diakses Melalui Laman: http://alsofwah.or.id/ekonomi_Islam/accessed Pada Tanggal 2 April 2016.

${ }^{38}$ Ummy Salamah, Tinjauan Hukum Islam., h. 50.

${ }^{39}$ Ibid., h. 51.
} 
Pihak pelaksana perjanjian juga berhak membatalkan perjanjian yang masih berlangsung kalau ia melihat lebih baik untuk dibatalkan saja, tentunya dengan memberikan kompensasi seimbang kepada pihak yang memiliki hasil perjanjian. Pihak hakim juga boleh membiarkan pelaksana untuk meneruskan pelaksanaannya kalau ia melihat itu lebih baik demi kemaslahatan pihak-pihak yang terikat dalam perjanjian tersebut. ${ }^{40}$

Berdasarkan uraian diatas, maka dapat disimpulkan bahwa lifetime warranty memiliki relevansi dengan khiyar aib. Ini bisa dilihat dari prinsip-prinsip yang ada dalam lifetime warranty sama dengan yang ada dalam khiyar aib. Semua unsur dan prinsip yang ada dalam lifetime warranty juga sesuai dan tidak ada yang bertentangan dengan hukum ekonomi syari'ah. Oleh sebab itu, maka lifetime warranty diperbolehkan dalam hukum ekonomi syari'ah.

Namun, meskipun lifetime warranty memiliki prinsip-prinsip yang sama dengan khiyar, namun lifetime warranty tidak sesuai jika sepenuhnya disandarkan kepada khiyar, aib karena khiyar aib merupakan hak memilih untuk meneruskan atau membatalkan akad, sedangkan lifetime warranty tidak dapat dibatalkan yang merupakan ketentuan-ketentuan dibuat secara sepihak oleh produsen dan disepakati oleh para pihak yang melakukan akad dan akadnya mengikat bagi para pihak.

Dengan adanya lifetime warranty, maka khiyar aib menjadi hilang, yaitu tidak adanya pembatalan transaksi ketika diketahui adanya cacat tersembunyi atau kerusakan pada obyeknya yang muncul di kemudian hari, baik disebabkan oleh faktor produksi massal akan tetapi produsen memberikan jaminan berupa ganti rugi sesuai dengan ketentuan yang berlaku.

\section{Kesimpulan}

Lifetime warranty dalam jual beli memiliki relevansi dengan khiyar aib. Ini bisa dilihat dari prinsip-prinsip yang ada dalam lifetime warranty, yang memiliki kesamaan dengan prinsip-prinsip yang ada dalam khiyar aib. Prinsip-prinsip yang tersebut antara lain adalah prinsip ar-Rhidha, persaingan sehat, kejujuran, keterbukaan dan keadilan. Jadi secara umum Life Time Warranty dalam jual beli dibolehkan menurut Hukum Ekonomi Syari'ah, karena prinsip-prinsip dalam Life Time Warranty tersebut sangat sesuai dan tidak ada yang bertentangan sama sekali dengan prinsip-prinsip khiyar aib yang ada dalam Hukum Ekonomi Syari'ah.

\footnotetext{
${ }^{40}$ Ibid.
} 


\section{DAFTAR PUSTAKA}

Adega Anggayasta, Analisis Pengaruh Produk Inti Dan Produk Peripheral terhadap Minat Beli Ulang Di Retronomic Boy Shop di Semarang, Skripsi di Universitas Diponegoro Semarang, 2011.

Al-Mushlih, Abdullah dan Shalah ash-Shawi, Ekonomi Islam: Hukum-Hukum Umum Dalam Perjanjian Usaha. Diakses Melalui Laman: http://alsofwah.or.id/ekonomi Islam/accessed Pada Tanggal 2 April 2016.

Amir Syarifuddin, Fiqh Muamalah, Jakarta: Pranada Media, 2005.

Andrian Sutedi, Tanggung Jawab Produk dalam Hukum Perlindungan Konsumen, Bogor: Ghalia Indonesia, 2008.

Anonim, Prinsip Jual Beli, Diakses Melalui Laman: http://dinulIslam.blogspot.com/2013/02/prinsip-jual-beli.html Pada Minggu 15 Mei 2016 Pukul 07.28 WIB.

Arie Siswanto, Hukum Persaingan Usaha, Bogor : Ghalia Indonesia. 2008.

Bermawi P. Iskandar, Manajemen Garansi Produk dan Perkembangannya di Indonesia, Makalah tidak dipublikasikan.

Chairuman Pasaribu dan Suhrawardi K. Lubis, Hukum Perjanjian dalam Islam, Jakarta: Sinar Grafika, 1996.

Enizar, Hadis Ekonomi, Jakarta: Raja Grafindo Persada, 2013.

M. Rofichul Nuril Abshor, dan Maria Anityasari, Analisis Perhitungan Biaya Garansi Untuk Produk Dengan Level Multiple Sub-Assemblies (Studi Kasus : Mesin Cuci LG 2 Tabung), dalam JURNAL TEKNIK POMITS, Vol. 1, No. 1, Surabaya: ITS, 2012.

Muhammad Fuad Abdul Baqi, Al-lu'lu'wal Marjanu Fima Itta Faqa'alaihi Asy-Syaykhani Al-Bukhariyyubwa Muslimun, Penerjemah; Muhammad Suhadi, dkk, dalam Mutiara Hadiths Sahih Bukhari Muslim, Jakarta:Ummul Qura, 2012.

Muhammad Nasib Ar-Rifa'i, TaisiruAl-Aliyyil Qadir Li Ikhtishari, Penerjemah: Syihabuddin, Jakarta: Gema Insani Press, 2012.

Muslich Sabir, Terjemah Riyadhus Shalihin II, Semarang: Toha Karya, 2004.

Peraturan Menteri Perdagangan Republik Indonesia Nomor 19/M-DAG/PER/5/2009.

Rachmadi, Hukum Jaminan Keperdataan, Jakarta: Sinar Grafika, 2009.

Rafik Issa Beekum, Etika Bisnis Islam, Yogyakarta, Pusta Pelajar: Pusta Pelajar, 2004.

Ummy Salamah, Tinjauan Hukum Islam Terhadap Garansi dalam Jual Beli, Skripsi di UIN Sunan Kalijaga Yogyakarta, 2002. 